\title{
PENYERAPAN DAN MOTIVASI UMAT ISLAM MENGEMBANGKAN FILSAFAT
}

\author{
Fathul Mufid \\ Sekolah Tinggi Agama Islam Negeri (STAIN) Kudus \\ e-mail: fathulmufid2013@gmail.com
}

\begin{abstract}
A touch of Hellenistic culture on Muslims was apparent in the first Umayyah caliph era, Mu'a>wiyah ibn Abi Sufya>n (41-60 H), who was kind to officially appoint high officers and his personal physician of the Roman scientists. At that very moment, the translation of books from Greco-Roman to Arabic had not been done, but the absorption of Greco-Roman culture was done by regular interaction or everyday conversation (social interaction). The aim of the paper is to track when the absorption of the Muslims started concerning on the Greco-Roman philosophy, because there is information that they, in first century of Hijriyah, had started copying Greek books into Arabic. According to historical data, at the time of the Umayah, the Caliph Kha>lid ibn Yazi>d had ordered a Greek scientist who lived in Alexandria to translate the Organon of Aristotle from Greek into Arabic. This paper is a literary study that particularly discusses the absorption process and the motivation of Muslims in developing a philosophy imported from the Greco-Roman, and some part of the world in general.
\end{abstract}

\begin{abstract}
Abstrak: Sentuhan budaya hellenistik pada umat Islam sebenarnya sudah nampak signalnya pada perilaku khalifah pertama Bani Umayyah, Mu'āwiyah ibn Abī Sufyān (41-60 H), yang dengan penuh toleran mengangkat pejabat tinggi dan dokter pribadinya dari ilmuan Romawi. Pada waktu itu memang kegiatan penerjemahan buku-buku Yunani-Romawi ke dalam bahasa Arab belum dilakukan, tetapi penyerapan budaya Yunani-Romawi dilakukan dengan jalan pergaulan biasa atau percakapan sehari-hari (interaksi sosial). Tujuan dari tulisan ini adalah untuk melacak sejak kapan penyerapan kaum Muslimin terhadap filsafat Yunani-Romawi, sebab ada informasi bahwa mereka sejak abad pertama Hijriyah telah memulai menyalin buku-buku Yunani ke dalam bahasa Arab. Menurut data sejarah, pada zaman Bani Umayyah, yaitu Khalifah Khālid ibn Yazī d telah memerintahkan seorang ilmuan Yunani yang berdomisili di Iskandariyah untuk menerjemahkan buku Organon karya Aristoteles dari bahasa Yunani ke dalam bahasa Arab. Tulisan ini merupakan kajian literer yang membahas tentang proses penyerapan dan motivasi umat Islam mengembangkan filsafat yang diimport dari Yunani-Romawi khususnya, dan belahan dunia lain pada umumnya.
\end{abstract}

Keywords: filsafat; Yunani; Romawi; Islam; al-Makmūn

\section{A. Pendahuluan}

Umat Islam semenjak dinasti Bani Umayyah yang didirikan oleh Mu’āwiyah ibn Abī Sufyān, cicit dari Umayyah ibnu Abdi Syām, telah bersentuhan dengan tradisi pemikiran filsafat Yunani-Romawi. Dinasti ini berkuasa selama sembilan 
dasawarsa (91 tahun), yakni mulai tahun 41 sampai tahun 132 Hijriyah, dengan menampilkan 14 orang khalifah. ${ }^{1}$ Sedangkan wilayah kekuasaan daulah Bani Umayyah meliputi seluruh jazirah Arabia, teluk Persi, Mesir, Afrika Utara, ke barat sampai ke Andalusia (Spanyol) dan ke timur sampai ke negeri Sind (India). Dipandang dari sudut sejarah perkembangan filsafat, sebagian daerah kekuasaan Bani Umayyah merupakan pusat kegiatan studi filsafat pada akhir zaman kuno.

Bermula dari ekspensi militer raja Macedomia, Iskandar Zulkarnain (356326 SM) ke kawasan Asia kecil dan Afrika utara yang melibatkan sejumlah prajurit dan kaum cendekiawan yang turut serta dalam ekspedisi tersebut. Melalui mereka, kebudayaan dan filsafat Yunani tersebar di daerah-daerah penaklukan yang melahirkan suatu kebudayaan baru yang dikenal dengan kebudayaan hellenisme, sebagai campuran antara kebudayaan Yunani dengan kebubayaan pribumi. Setelah Iskandar Zulkarnain meninggal pada tahun 323 SM, kerajaannya pecah menjadi tiga bagian, yaitu: Macedonia di Eropa, kerajaan Ptelomeus di Mesir dengan ibu kota Iskandariyah dan kerajaan Seleucid di Asia. Raja-raja Ptelomeus di Mesir mendirikan universitas Iskandariyah sebagai pusat studi ilmu pengetahuan dan filsafat, yang kemudian berkembang dengan pesat berkat datangnya para mahaguru dari Athena yang diusir dari Yunani. Universitas Iskandariyah terohor di seluruh dunia, karena mahagurunya terdiri dari para pakar yang berbobot seperti Archemides dalam ilmu fisika, Galenus dalam ilmu kedokteran, Ptelomeus dalam ilmu falak, dan Plotinus dalam ilmu filsafat. $^{2}$

Universitas Iskandariyah tetap menjadi pusat studi filsafat sampai abad ke$6 \mathrm{M}$, sehingga ketika umat Islam menaklukkan kota tersebut di sana masih terdapat perpustakaan besar, teleskop dan berbagai laboratorium penelitian. Berkat adanya sarana di atas, serta lahirnya ahli pikir generasi kedua di Iskandariyah yang telah mengatur dan menyusun buku-buku generasi pertama, maka meratakan jalan bagi umat Islam untuk mempelajari berbagai cabang ilmu pengetahuan dan filsafat. Pusat perkembangan kebudayaan Yunani selain di Iskandariyah, terdapat juga di Jundaisabur yang letaknya tidak jauh dari

1A. Shalabi, Mawsū'at al-Tārīkh al-Islām, jilid II (Mesir: al-Nahḍah al-Mișriyyah, 1971), h. 22.

${ }^{2}$ Ahmad Daudy, Kuliah Filsafat Islam (Jakarta: Bulan Bintang, 1986), h. 2. 
Baghdad sekarang, dan kota Ḥarrān yang terletak di negeri Syām (Syiria). Sewaktu kota Jundaisabur masuk kekuasaan daulah Bani Umayyah, di sana telah ada suatu akademi filsafat dan sebuah rumah sakit yang dipimpin oleh Girgis ibn Bakhtiyashu. Kota ini menjadi pusat studi ilmu pengetahuan dan filsafat, bermula dari kekalahan tentara Romawi oleh panglima Persia yang bernama Sabur, sehingga banyak serdadu Romawi yang ditawan di kota tersebut.

Di antara para tawanan perang tersebut terdapat para ilmuan dan ahli pikir yang diberi kebebasan oleh Kisra Persia untuk mengembangkan keahlian mereka masing-masing. Terlebih lagi, ketika kaisar Romawi, Justinianus pada tahun 529 M menutup seluruh perguruan filsafat di Athena, serta mengusir para filosof dari Romawi, mereka sebagian mengungsi ke Jundaisabur dan Harrān. Persia menyambut gembira kedatangan mereka dengan disediakannya fasilitas yang memadai untuk mereka. Sejak waktu itu, Jundaisabur menjadi pusat kelahiran kembali filsafat dan kedokteran, berkat penerjemahan buku-buku Yunani-Romawi ke dalam bahasa Suryani dan Persia. Dengan kedua penerjemahan bahasa inilah umat Islam menyalin pemikiran Yunani-Romawi ke dalam bahasa Arab. ${ }^{3}$

Berangkat dari laporan sejarah perkembangan filsafat di atas, menunjukkan bahwa penduduk pribumi kota Iskandariyah (Mesir), Jundaisabur (Persia) dan Harran (Syām) pada masa Bani Umayyah telah memiliki kebudayaan hellenistik dan bahkan sebagai pusat studi filsafat, dengan berdirinya lembaga-lembaga akademis. Dengan dikuasainya kota-kota tersebut oleh umat Islam, maka terjadilah interaksi sosial yang mendalam antara umat Islam (pendatang) dengan bangsa pribumi. Gejala sosial ini mengakibatkan adanya akulturasi kebudayaan, tidak hanya perilaku sosial tetapi juga alam pemikiran dari khasanah intelektual Yunani-Romawi. Kesimpulannya adalah, bahwa umat Islam pada zaman Bani Umayyah telah berada pada posisi interaksi dengan warisan intelektual YunaniRomawi yang merupakan embrio lahirnya filsafat Islam.

Umat Islam pada zaman Bani Umayyah menurut laporan sejarah juga berkenalan dengan filsafat Yunani-Romawi malalui kaum Masehi Timur, sebab aliran Kristen Timur tersebut sudah sejak abad kedua Masehi telah mempelajari

3Aḥmad Fuād al-Akhwān̄̄, al-Falsafah al-Islāmiyyyah, terj. (Jakarta: Pustaka Firdaus, 1985), h. 31.

JURNAL THEOLOGIA — Volume 27, Nomor 1, Juni 2016 
filsafat Yunani-Romawi dengan menerjemahkan buku-buku Yunani ke dalam bahasa Suryani. Ketika khalifah Bani Umayyah di pegang oleh Marwān ibn Hakam (64-65 H.), penerjemahan buku-buku Yunani mulai dilakukan umat Islam untuk tujuan tertentu. Pada mulanya terjemahan dilakukan pada bukubuku ilmiah yang berhubungan dengan kehidupan praktis, seperti kimia, kedokteran, astronomi dan lain-lain. Tetapi kemudian berkembang pada bidang filsafat, karena ilmu pengetahuan dan filsafat pada waktu itu merupakan satu kesatuan yang tidak terpisahkan. Ilmu pengetahuan pertama yang diterjemahkan orang Islam ialah ilmu kedokteran. Seorang dokter ternama Musarjawaih menerjemahkan buku kedokteran yang di tulis oleh pendeta Ahrān ibn A'yūn dalam bahasa Suryani ke dalam bahasa Arab. Buku tersebut masih tersimpan baik di perpustakaan sampai zaman Khalifah Umar ibn Abd. Azīz (99-101 H), yang selanjutnya buku tersebut dikeluarkan agar dapat dibaca kaum Muslimin yang berminat, setelah khalifah lebih dahulu salat istikhārah. Khalifah Umar ibn Abd Aziz menginginkan supaya buku-buku ilmu pengetahuan yang bermanfaat bagi kesejahteraan rakyat seperti kedokteran, kimia, dan geometri dikeluarkan dari perpustakaan agar dipelajari umat Islam. Sejak saat itu mulailah berbagai cabang ilmu pengetahuan asing sedikit demi sedikit diserap oleh dunia Islam sampai zaman Daulah Abbasiyyah. ${ }^{4}$

Hasan Ibrāhīm Hasan melaporkan, bahwa orang pertama yang menaruh perhatian kepada pengkajian filsafat dan penerjemahan buku-buku kedokteran ke dalam bahasa Arab adalah Khālid ibn Yazīd ibn Mu’āwiyah (85-84 H). Ia memanggil sekelompok orang Yunani yang bermukim di Mesir untuk menyalin buku-buku yang berbahasa Yunani dan Qibti (Mesir) tentang kimia ke dalam bahasa Arab. ${ }^{5}$ Khālid ibn Yazīd juga memerintahkan seorang ilmuan Yunani yang berdomisili di Iskandariyah untuk menerjemahkan buku Organon dari bahasa Yunani ke dalam bahasa Arab. ${ }^{6}$

Berangkat dari fakta sejarah di atas, muncul pertanyaan mendasar mengapa umat Islam yang telah memiliki al-Qur'an dan al-Hadis sebagai pedoman dan pandangan hidup dengan kesempurnaan ajarannya, masih perlu dan tertarik memelajari filsafat Yunani-Romawi, sehingga melahirkan disiplin filsafat

${ }^{4}$ Ibid, h. 32.

${ }^{5}$ Hasan Ibrāhīm Hasan, Tārīkh al-Islām, jld. II (Mesir: al-Nahḍah al-Miṣriyyah, 1976), h. 345.

${ }^{6}$ Ali Shāmī al-Nashār, Manāhijal-Bahthi índa Mufakkir al-Islām (Dārul Fikr al-Arabī, 1994), h. 7. 
Islam. Bagaimana proses penyerapannya, dan apa yang menjadi motivasi umat Islam melakukan hal tersebut, serta apa sebenarnya tujuan mereka?

\section{B. Proses Penyerapan Filsafat Yunani-Romawi}

Sebelum datangnya Islam, terdapat beberapa pusat studi kebudayaan Yunani-Romawi yaitu; Iskandariyah (Mesir), Harrān, Urfā (Rahā), Nusaibain, Jundaisabur dan Baghdad. ${ }^{7}$ Kota Athena Yunani tetap menjadi pusat studi filsafat yang penting, di mana sekolah-sekolah filsafat di Athena seperti model akademi (Plato) dan model lykeion (Aristoteles) tetap diteruskan aktivitasnya. Filsafat Yunani yang sampai pada dunia Islam tidaklah semuanya orisinil seperti yang ditinggalkan orang-orang Yunani sendiri, tetapi telah melalui pemikiran hellenisme Romawi yang memiliki ciri dan corak tertentu. Jika pemikiran filsafat Yunani cenderung bersifat teoritis, maka filsafat hellenisme Romawi lebih bercorak praktis. Hal ini disebabkan Bangsa Romawi telah menguasai ketatanegaraan, hukum dan perundang-undangan. Sebagai mata rantai yang menghubungkan filsafat Yunani kepada umat Islam, maka perlu dipaparkan berbagai perkembangan filsafat Yunani yang berpengaruh kepada para filosof Muslim sebagai berikut:

\section{Aliran Iskandariyah}

Raja-raja Ptelomeus di Mesir mendirikan Universitas di Iskandariyah sebagai pusat studi ilmu pengetahuan yang kemudian berkembang dengan pesat berkat kedatangan mahaguru tinggi Athena yang diusir dari Yunani. Universitas Iskandariyah ini sangat termasyhur di zaman itu, sehingga menarik para mahasiswa untuk belajar karena letaknya yang strategis antara Timur dan Barat. Di samping itu, karena para mahagurunya terdiri dari para ilmuwan yang tersohor, seperti Archemides dalam Ilmu Fisika, Galinus dalam ilmu kedokteran, Ptelomeus dalam ilmu falak dan Plotinus dalam ilmu filsafat. ${ }^{8}$ Ahmad Fuād alAhwānī menjelaskan, bahwa filsafat dan ilmu pengetahuan berkembang di Iskandariyah hingga abad ke enam Masehi hingga lahirnya ahli pikir generasi kedua yang mengatur, menyusun dan mempelajari buku-buku peninggalan

${ }^{7}$ Ahmad Daudy, Kuliah Filsafat Islam, h. 1.

8Ibid., h. 2.

JURNAL THEOLOGIA — Volume 27, Nomor 1, Juni 2016 
generasi pertama sebagai bahan pengajaran. Dari para ahli pikir generasi kedua inilah orang-orang Islam menerjemahkan berbagai cabang ilmu perngetahuan.9

Para mahaguru di universitas tersebut tetap melanjutkan tradisi ilmiah, hingga umat Islam menaklukkan kota tersebut yang di sana masih terdapat perpustakaan besar, teleskop, dan berbagai laboratorium penelitian. Berkat adanya sarana di atas, umat Islam dapat memanfaatkannya untuk mengkaji studi ilmu matematika, fisika, sastra, seni dan juga filsafat.

\section{Aliran Jundaisabur dan Ḥarrān}

Pada abad ketiga Masehi, pusat-pusat kebudayaan Yunani bertambah di kota Jundaisabur yang letaknya tidak jauh dari Baghdad (sekarang), dimana waktu kota tersebut masuk ke dalam kekuasaan daulah Islamiyah telah ada satu akademi dan sebuah rumah sakit yang dipimpin oleh Girgis Ibn Bakhtiyashu. Kota ini didirikan oleh seorang panglima Persia yang bernama Sabur setelah dapat mengalahkan angkatan perang bangsa Romawi, sehingga dapat merebut Syām dan Antiokia. Setelah Kaisar Romawi Justinianus mengusir para filosof dari perguruan Athena, mereka pindah ke Jundaisabur, sehingga kota ini menjadi pusat kelahiran kembali ilmu filsafat dan kedokteran Yunani. Sejak saat itu, sebagian besar buku-buku filsafat dan ilmu pengetahuan Yunani diterjemahkan ke dalam bahasa Suryani, di samping ke dalam bahasa Persia. Dari terjemahan kedua bahasa inilah umat Islam pada awal daulah Bani Abbasiyyah menerjemahkannya ke dalam bahasa Arab, seperti yang dilakukan oleh Ibnu al-Muqaffā terhadap semantika Aristoteles. ${ }^{10}$

Di samping Jundaisabur, kota Harrān yang terletak di bagian utara negeri Syām (Syiria) juga merupakan pusat studi ilmu pengetahuan, terutama bidang ilmu falak karena berkaitan dengan bintang-bintang yang menjadi objek penyembahan sebagian penduduk. Setelah kota ini jatuh di bawah kekuasaan umat Islam, maka semakin terbuka sebagai pusat studi filsafat terutama Neo Platonisme dan berbagai mazhab keagamaan bangsa-bangsa Semit.11

${ }^{9}$ Aḥmad Fuād al-Akhwānī, al-Falsafah al-Islāmiyyah, h. 22.

10Ibid., h. 31

11Ahmad Daudy, Kuliah Filsafat Islam, h. 2. 


\section{Aliran Nestorit dan Yakobit}

Ada dua aliran dalam agama Kristen yang sangat besar perhatiannya terhadap filsafat pada abad-abad permulaan, yaitu aliran Nestorit dan Yakobit. Dua aliran ini mempunyai perbedaan paham terutama tentang hakikat unsur lāhūt dan nāsūt pada diri Yesus Kristus, sehingga masing-masing aliran terdorong mempelajari filsafat Yunani untuk dipergunakan dalam mempertahankan pendirian masing-masing. Para pendeta Nestorit di pusat studi agama di Urfā (Rahā) dan Nusaibain melakukan penerjemahan berbagai buku filsafat Yunani ke dalam bahasa Suryani, demikian pula para pendeta Yakobit di pusat studi agama di Syiria dan Gonistrin. Hal ini dilakukan karena masing-masing memandang perlu memakai filsafat Yunani untuk mempertahankan dan membela kebenaran akidah yang dianut, serta dapat dipergunakan untuk membatalkan akidah lawan.12

Memang filsafat lebih dahulu berkembang di Iskandariyah, tetapi kemudian sejak abad ke-4 M mulai meluas ke arah timur, setelah agama Nasrani dapat mengalahkan Paganisme Yunani, Mesir kuno, dan Romawi, sehingga filsafat meluas sampai di Syām dan jazirah Arabia. Sejak itu kaum Nasrani Suryan banyak tertarik mempelajari filsafat untuk diterjmahkan ke dalam bahasa Suryani. ${ }^{13}$ Jadi menjelang datangnya agama Islam kawasan tersebut telah menjadi daerah yang dipenuhi berbagai kebudayaan baik yang berasal dari Timur maupun Barat.

\section{Aliran Baghdad}

Ketika dinasti Bani Umayyah memindahkan pusat kekhalifahan dari Hijaz ke Damaskus (Syām), maka kota Basrah dan Kufah memainkan peranan penting dalam sejarah pemikiran Islam. Kemudian setelah daulah Islamiyah pindah ke tangan dinasti Bani Abbasiyyah dengan membangun kota Baghdad sebagai ibu kota, maka peranan kota Kufah dan Basrah pindah ke kota baru itu, sehingga Baghdad menjadi mercusuar kegiatan ilmu, filsafat dan peradaban di Timur dalam waktu yang lama. Khalifah Abbasiyyah kedua, al-Manșūr mendatangkan Girjis bin Bakhtiyashu $(148 \mathrm{H})$ dari Jundaisabur untuk diangkat sebagai kepala

12Ibid,, h. 4.

${ }^{13}$ Ibid., h. 29. 
team dokter istana sampai beliau wafat pada tahun $150 \mathrm{H}$. Girjis tetap menjadi kepala team dokter istana Abbasiyyah dalam masa Khalifah al-Mahdi al-Hādi, dan Hārun ar-Rasyīd. ${ }^{14}$

Selanjutnya di bawah pemerintahan Hārun al-Rasyīd, penerjemahan bukubuku Yunani ke dalam bahasa Arab dimulai dengan jalan mengirimkan team untuk membeli manuskrip ke kerajaan Romawi. Pada mulanya yang dipentingkan ialah buku-buku mengenai kedokteran kemudian berkembang pada buku ilmu pengetahuan lainnya serta filsafat. Buku-buku itu terlebih dahulu diterjemahkan ke dalam bahasa Siriac, kemudian baru ke dalam bahasa Arab, tetapi akhirnya penerjemahan dilakukan langsung ke dalam bahasa Arab. ${ }^{15} \mathrm{Di}$ antara para penerjemah itu ialah Hunain bin Ishāā, Thābit bin Qurrā, Qustā bin Luqā Hubaeisy bin al-Așām, dan lain-lain yang semuanya bukan beragama Islam. Setelah khalifah dipegang oleh al-Makmūn (183-233 H) kegiatan penerjemahan mencapai puncaknya dengan berdirinya suatu akademi yang bernama Bayt al-Hikmah atas prakarsa khalifah al-Makmūn. Di sana disediakan fasilitas yang memadai untuk menopang kegiatan penerjemahan berbagai ilmu pengetahuan dan filsafat.

Hunain bin Isḥāq diangkat sebagai ketua Bayt al-Hikmah yang bertugas memilih buku-buku yang akan diterjemahkan serta mengawasi balai tersebut dalam kegiatan akademisnya. Ia sendiri menguasai bahasa Arab dan Yunani, sehingga berhasil menerjemahkan 20 buku Galen ke dalam bahasa Siriac, dan 14 buku lainnya ke dalam bahasa Arab. Hunain mempunyai 90 pembantu dan murid dalam penerjemahan ini. ${ }^{16}$ Setelah khalifah al-Makmūn meninggal, kegiatan penerjemahan tetap berjalan terus meskipun tidak menjadi urusan istana, tetapi sebagai kegiatan pribadi-pribadi atau kelompok yang cinta ilmu pengetahuan dan filsafat.

Perlu diketahui pula, bahwa di belahan bumi Andalusia (Spanyol), umat Islam juga mengalami masa kejayaan dengan berdirinya Universitas Cordoba, Granada, Seville dan Malaga di bawah pemerintahan Bani Umayyah di Spanyol. Khalifah mengundang guru-guru besar dari Timur serta melengkapi per-

14Ibid., h. 33.

${ }^{15}$ Harun Nasution, Filsafat dan Mistisisme dalam Islam (Jakarta: Bulan Bintang,1979), h. 11.

16Ibid., h. 12. 
pustakaan dengan membeli atau menyalin buku-buku dari Iskandariyah, Damaskus, dan Baghdad. Memang erat sekali hubungannya antara filsafat Yunani-Romawi dengan filsafat Islam, sebab sesuai dengan latar belakang sejarah perkembangan filsafat, Yunani-Romawi merupakan periode kejayaan filsafat yang pertama, sedang filsafat Islam sebagai periode kejayaan kedua. Kemudian gerakan renaisance di Eropa dan filsafat modern di Barat merupakan periode kejayaan filsafat ketiga. Jadi filsafat Islam merupakan mata rantai yang tidak terpisahkan dalam kelangsungan hidup dunia filsafat pada umumnya.

Filsafat Islam sebagai periode kedua, logis banyak mengambil pemikiran dari para filosof periode pertama (Yunani-Romawi) terutama pikiran Plato, Aristoteles, dan Plotinus, di samping aliran Stoa. Ada empat aliran filsafat Yunani yang berkembang sebelum Plato dan Aristoteles dan banyak mempengaruhi pikiran kedua filosof itu, meskipun mereka berhasil memadukan pikiran aliranaliran tersebut menjadi suatu pikiran filsafat yang sistematis, yaitu aliran keTuhanan, aliran mistik, aliran kemanusiaan, dan aliran naturalis $\left(t a \bar{b} b i^{\prime}\right){ }^{17}$ Pemikiran aliran filsafat Yunani di atas, ternyata mempengaruhi filosof besar seperti Plato, sehingga meskipun ia mengakui adanya dunia idea (Tuhan), tetapi tidak jelas pendapatnya tentang qadìm atau hädith-nya alam. Demikian pula Aristoteles, yang mengakui ke Esaan sumber alam semesta yaitu Zat Yang wājib wujūd (Tuhan), tetapi ia membenarkan azalinya alam dan keabadian jiwa, sehingga menyebabkan adanya pluralisme (bilangan) pada alam yang qadim. Kedua filosof inilah yang pemikirannya banyak mempengaruhi para filosof Muslim, terutama Aristoteles yang aliran filsafatnya dikenal dengan sebutan alhikmah al-mashshä'iyyah di kalangan orang Arab. Di samping pemikiran dua filosof Yunani tersohor yang memang banyak mewarnai para filosof Muslim dalam filsafatnya, juga nampak jelas adanya pengaruh dari filosof hellenisme Romawi yang berkembang setelah Plato dan Aristoteles, yaitu aliran Stoa, yang didirikan oleh Zeno (336-264 SM), aliran Epicure yang dinisbatkan dengan pendirinya Epikuros (341-370 SM), dan aliran skepsis yang di tokohi oleh Pyrrho (365-275 SM). ${ }^{18}$

Fase terakhir dari filsafat hellenisme Romawi adalah aliran Neo Platonisme, yang merupakan fase menghidupkan kembali filsafat Plato (427-347 SM),

17Poerwantana, dkk. Seluk Beluk Filsafat Islam (Bandung: Rosda, 1988,) h. 72-73.

18Poedjawijatna, Pembimbing ke Arah Filsafat (Jakarta: Pembangunan, 1980), h. 40-43. 
bukan semata-mata menciptakan yang baru. Meskipun aliran ini bercorak agama, tetapi masih berkisar pada filsafat Yunani, tasawuf Timur, memilih dari sana dan sini, kemudian disintesakan. Di dalamnya terdapat unsur-unsur Pytagoras, Aristoteles, Stoa, dan terutama Platonisme, di samping tasawuf Timur. Sebagai pencipta aliran ini ialah Plotinus (203-269 M) yang lahir di Mesir. Ia baru mulai mengarang pada usia 49 tahun, dan setelah meninggal pada tahun 269 M, karya-karyanya dikumpulkan muridnya yang bernama Porphyrios dalam suatu kumpulan yang disebut Ennedes. Kumpulan tersebut terdiri dari 54 karangan pendek, yang terkumpul dalam 6 kelompok dan masing-masing terdiri dari 9 karangan kecil, yang berisi bermacam-macam persoalan. ${ }^{19}$

Aliran Neo Platonisme inilah yang datang kepada kaum Muslimin melalui aliran Masehi di Timur dekat tetapi dengan baju lain, yaitu tasawuf Timur dan ke-Esa-an Tuhan, Zat "Yang Pertama" dengan ketunggalan yang sebenarbenarnya. Sistem filsafat Plotinus berkisar pada konsep kesatuan, sehingga semua alam wujud ini selalu berhasrat untuk kembali kepada "Yang Satu". Dengan demikian berarti ada dua persoalan pokok dalam sistem filsafat Plotinus yang merupakan gerakan dua arah. ${ }^{20}$ Karenanya kaum Muslimin tertarik dengan aliran tersebut dan menganggap filsafat Yunani tidak bertentangan dengan Islam, karena mengakui ke-Esa-an Tuhan dan menganggap zuhud sebagai jalan kebahagiaan bagi manusia, meskipun sering kelihatan bertentangan satu sama lain.21 Melalui Neo Platonisme inilah kaum Muslimin dapat mengenal filsafat Yunani terutama Plato, Aristoteles, dan aliran Stoa.

\section{Sebab-sebab Penerimaan Filsafat Yunani}

Sejak munculnya al-Kindī sebagai filosof pertama di kalangan umat Islam, dunia Islam nampak bersikap senang hati untuk menerima filsafat Yunani, sehingga setelah al-Kindī disusul oleh filosof-filosof Muslim yang lain dan bahkan lebih berbobot seperti al-Farābī, al-Rāzī, Ibnu Miskawaih, dan Ibn Sīnā. Kemudian baru terjadi penolakan terhadap filsafat oleh al-Ghazāli dengan bukunya Taḥāfut al-Falāsifah pada pertengahan abad ke-5H. Meskipun demikian di sisi lain, alGhazāli juga dapat menerima pemikiran Yunani di luar soal metafisika. Oleh

${ }^{19}$ A. Hanafi, Pengantar Filsafat Islam (Jakarta: Bulan Bintang, 1978), h. 87.

${ }^{20}$ A. Chairil Basori, Filsafat (Semarang: IAIN Walisongo, 1987), h. 51.

${ }^{21} \mathrm{Abu}$ Ahmadi, Filsafat Islam (Semarang: Thoha Putra, 1982), h. 49. 
sebab itu, sebenarnya al-Ghazāli juga dapat di pandang sebagai filosof Muslim. Sepeninggal al-Ghazāli di belahan dunia Islam Andalusia (Spanyol) muncul juga generasi kedua, seperti Ibn Bajjah (w. 1138 M), Ibn Thufail (1110-1185 M), dan yang tersohor ialah Ibn Rusyd (1126-1198 M), yang telah menyusun buku tahāfut at-tahāfut untuk membela filsafat dari serangan al-Ghazāli.

Hanafi mengelompokkan sebab-sebab penerimaan umat Islam terhadap filsafat Yunani menjadi dua faktor: Pertama, faktor subjektif yaitu kecondongan umat Islam pada waktu itu untuk dapat menyampaikan ajaran agama Islam secara rasional kepada umat non-Muslim agar dapat di terima oleh mereka secara sadar dan tanpa adanya keraguan. Hal inilah merupakan salah satu faktor yang mengharuskan umat Islam untuk berfilsafat. Kedua, faktor objektif yang meliputi tiga hal sebagai berikut:

1. Ketelitian logika Aristoteles dan ilmu-ilmu matematika yang cukup mengagumkan dunia pikir umat Islam, sehingga mereka mempercayai kebenaran logika dan kejelasan seluruh hasil pemikiran Yunani, termasuk dalam lapangan metafisika (ketuhanan).

2. Corak keagamaan pada filsafat Yunani ketika menggambarkan Tuhan dan kebahagiaan manusia. Tuhan di gambarkan sebagai Tuhan Yang Esa, dan jalan kebahagiaan ialah zuhud dan tasawuf, serta peleburan diri kepada Tuhan sebagai jalan pendekatan manusia kepada-Nya.

3. Bercampur aduknya pikiran-pikiran keagamaan dari kalangan Yahudi dan Masehi yang bercorak filsafat dengan buku-buku filsafat Yunani, sehingga ketika terjadi penerjemahan, buku-buku keagamaan ini di sangka umat Islam sebagai karangan filosof-filosof Yunani. Faktor-faktor itulah yang menyebabkan filsafat Yunani di terima umat Islam, meskipun penerimaannya tidak secara keseluruhan, tetapi diadakan penyesuaian-penyesuaian dengan nas-nas agama, di samping pemikiran yang sedang perkembang di kalangan umat Islam sendiri.22

Berangkat dari dua faktor di atas, umat Islam berupaya mengintegrasikan filsafat dengan ajaran agama Islam melalui usaha pemaduan, dengan dua model, yakni:

${ }^{22}$ A. Hanafi, Pengantar Filsafat Islam, h. 61 
1. Memberikan ulasan terhadap pikiran-pikiran filsafat Yunani, dengan menghilangkan kejanggalan-kejanggalan serta mempertemukan pikiran filsafat yang berlawanan dengan ajaran agama.

2. Pemaduan antara filsafat dengan agama. Cara ini lebih nampak sebagai penerimaan kepada filsafat Yunani, sebab usaha untuk menghilangkan perlawanan antara filsafat dan agama berarti para filosof Muslim tidak kurang kepercayaan mereka terhadap agama Islam. Kedua-keduanya dianggap sederajat, maka cara kedua ini mendorong filosof Muslim untuk menjelaskan ketentuan-ketentuan agama dengan pemikiran yang terurai sejalan dengan filsafat, seperti nampak pada al-Farābī, Ibn Sinā dan Ikhwānus șafā. Di samping itu, cara pemaduan ini dilakukan mereka dengan mena'wilkan kebenaran-kebenaran agama dengan ta'wilan yang sesuai dengan filsafat, sebagaimana dilakukan al-Farābī, Ibn Sinā dan juga Ibn Rusyd. 23

\section{Motivasi Umat Islam Mengembangkan Filsafat}

Peradaban Islam pada puncak kebesarannya tidak menentang ilmu pengetahuan dan filsafat, bahkan menguatkan, mendorong serta bersungguhsungguh dalam mencari kebenaran dan membuka pintu lebar-lebar bagi berbagai macam pendapat dan aliran. Islam mengajak umatnya untuk memikirkan, menganalisis dan mengarahkan pandangan ke langit dan ke bumi serta tidak mengharamkam pembahasan yang rasional filosofis. Di sisi lain setelah umat Islam menguasai daerah-daerah penaklukan, pergaulan mereka dengan masyarakat setempat sangat toleran, sehingga banyak orang Yahudi dan Nasrani yang tertarik memeluk agama Islam. Sementara itu bagi mereka yang tetap pada agama semula, juga mendapatkan tempat yang terhormat di sisi para khalifah, di samping banyak pula kaum Muslimin yang kawin dengan wanita Yahudi maupun Nasrani.

Setelah umat Islam menguasai berbagai daerah seperti Mesir, Persia dan lain sebagainya, mereka sadar bahwa di tengah-tengah mereka terdapat orang orang yang telah memiliki budaya intelektul yang tinggi, baik dari orang Kristen maupun lembaga-lembaga keagamaan lainnya. Menurut analisa seorang orientalis, W. Montgomery Watt, bahwa sebab penerimaan orang Islam

23Poerwantana, dkk. Seluk Beluk Filsafath. 100-101. 
terhadap filsafat Yunani ialah kesadaran mereka sendiri untuk membela keyakinan agama, karena di antara orang orang pribumi banyak yang menolak atau mengkritik sebagian 'aqïdah Islämiyyah dengan argumentasi filosofis. Oleh sebab itu, kebutuhan akan polemik dan apologi untuk membela agama Islam, mendorong sebagian umat Islam untuk mempelajari filsafat. 24

Pendapat Watt di atas, merupakan salah satu faktor eksternal bagi kaum Muslimin yang beraliran rasionalis dalam mempelajari filsafat dengan dalih untuk membela keyakinan agama terhadap kritik yang berasal dari umat nonMuslim. Ada di antara aliran teologi pada masa Bani Umayyah yang jalan pikirannya terkena sentuhan filsafat Yunani yaitu aliran Qadariyah dan Mu'tazilah. Aliran Qadariyah merupakan aliran teologi Islam pada akhir abad pertama Hijriyah yang telah membicarakan masalah qudrah dan irädah manusia ('afāal al-ibād), sebagai suatu kebebasan baginya lepas dari qudrah dan irädah Allah, dan bahkan Tuhan tidak mengetahui apa yang diperbuat oleh manusia. Perdebatan tersebut menurut Ahmad Amin, semula merupakan pendapat filosof Yunani, yang kemudian ditransfer oleh orang-orang Suryani, dan selanjutnya menjadi pembicaraan orang-orang Zoroaster dan Masehi. ${ }^{25}$

Aliran Mu'tazilah mempertahankan pendapat tersebut, bahkan lebih diperdalam dan lebih bersifat filosofis, sebab mereka tidak hanya mempersoalkan qudrah dan irädah manusia, tetapi telah lebih jauh pada persoalan metafisika. Misalnya, Wāṣil bin 'Ațā' berpendapat bahwa Allah adalah Maha Esa, karenanya ia menolak adanya sifat-sifat Tuhan ( $m u^{\prime} a t t ̦ i l a h$ ) dalam arti sifat-sifat Tuhan itu sebenarnya bukanlah sifat yang mempunyai wujud tersendiri di luar Zat Tuhan, tetapi merupakan sifat essensi Tuhan. Hanya Allahlah yang qadim, dan tidak ada selain Dia yang qodìm, sehingga pendapat orang bahwa sifat-sifat Tuhan itu qadìm, berarti menunjukkan adanya qadìm yang berbilang. ${ }^{26}$ Fakta lain sentuhan filsafat Yunani terhadap aliran Mu'tazilah, yaitu pendapatnya bahwa dengan akal belaka manusia sanggup mengetahui baik dan buruk, meskipun syara' tidak menyebutkannya. Manusia wajib menjalankan yang baik 58.

${ }^{24}$ Montgomery Watt, Islamic Theology and Philosophy, terj. Umar Basalim (Jakarta, P3M, 1987), h.

${ }^{25}$ Ahmad Amīn, Fajr al-Islām (Mesir: al-Nahḍah al-Mișriyyah, 1965), h. 284. Harun Nasution, Filsafat dan Mistisme, h. 21

${ }^{26}$ De Boer, The History of Philosophy in Islam, terj. Edward R. Jones BD (New York: Dover Publication INC, 1967), h. 45. 
dan meninggalkan yang buruk tanpa diutusnya seorang Rasul. Berangkat dari pendapat ini, maka al-Shahrastanī menyimpulkan, bahwa para mutakallimin klasik serperti Wāșil bin 'Ațā’ dan teman-temannya telah mempelajari bukubuku filsafat ${ }^{27}$

Setelah kekuasaan umat Islam dipegang dinasti Bani Abbasiyyah, aktivitas penerjemahan buku-buku asing semakin pesat, yang dimulai oleh Khalifah kedua, yaitu Ja'far al-Manșūr dengan membangun kota Baghdad yang menjadi mercusuar dan jantung dunia dalam beberapa abad. ${ }^{28}$ Khalifah ini sangat mencintai ilmu pengetahuan astronomi, kedokteran dan juga ilmu hitung. Ia menyuruh Muhammad bin Ibrāhīm al-Fazāzī (ahli falak pertama dalam Islam) untuk menerjemahkan buku Sirhind dari India ke dalam bahasa Arab, yang berisi ilmu astronomi dan ilmu hitung India. Dari bahasa Persia di terjemahkan buku Kalīlah wa Daminah, sedang dari buku-buku Yunani di terjemahkan melalui bahasa Suryani. Kegiatan ini masih berjalan pada masa Khalifah alMahdī, al-Hādī dan al-Rasyīd yang menyuruh menerjemahkan buku Enclides tentang ilmu ukur, dan buku Almageste karya Ptolemeus tentang ilmu falak. ${ }^{29}$

Gerakan penerjemahan mencapai puncaknya pada masa Khalifah alMakmūn (813-833 M) di Baghdad. Sebagai penganut faham Mu'tazilah, ia bersikap liberal untuk pengetahuan rational, dengan mendirikan wisma kearifan Bayt al-Hikmah sebagai pusat kegiatan ilmiah. Di tangan al-Makmūn ilmu pengetahuan dan filsafat yang pernah berkembang di Yunani, Romawi dan Timur dekat ditransfer bahkan dikuasai dan akhirnya dikembangkan umat Islam secara menakjubkan. Ia mengirim utusan ke seluruh kerajaan Bizantium untuk mencari buku-buku Yunani tentang berbagai bidang, yang kemudian diterjemahkan ke dalam bahasa Arab di dalam lembaga akademis Bayt alHikmah tersebut.

Di antara pakar-pakar penerjemah pada masa itu ialah Hunain bin Isḥak, Ya'qūb al-Kindī, Țābit bin Qurrā dan Umar bin Baktiyakshu. Mereka dibantu beberapa staf, sehingga dapat berhasil menerjemahkan buku-buku Yunani, Romawi, dan Persia dari berbagai disiplin ilmu seperti; filsafat, kedokteran, astronomi, matematika, musik, logika, sejarah, hukum, sastra, dan lain

27 al-Shahrastanī , al-Milal wa an-Niḥal, Juz I (Mesir: al-Qāhirah, 1320), h. 58.

${ }^{28}$ Syalabi, Ahmad, Sejarah Kebudayaan Islam (Jakarta: Pustaka al-Husna, 1987), h. 246.

29lbid,, h. 247. 
sebagainya. Di antara pakar tersebut, al-Kindīlah yang beruntung memperoleh kedudukan yang baik dari Khalifah al-Ma'mūn, al-Mu'tașim dan al-Wathīq sebagai guru istana di samping sebagai dokter pribadi. ${ }^{30}$

Kondisi umat Islam seperti di atas, membawa akibat adanya akulturasi kebudayaan dengan asing, sehingga menimbulkan perbedaan pendapat di dalam memahami soal-soal agama di kalangan kaum Muslimin sendiri. Perbedaan tersebut menimbulkan berbagai aliran dan golongan di kalangan umat Islam, yang masing-masing aliran berusaha untuk mempertahankan pendapatnya dalam mengalahkan lawan, sehingga perlu bahan dan teknik berdebat dari manapun asalnya. Hal ini merupakan salah satu motivasi bagi umat Islam menerjemahan buku-buku asing terutama filsafat.

Secara lebih rinci, motivasi penerjemahan buku-buku filsafat ke dalam bahasa Arab oleh umat Islam adalah sebagai berikut:

1. Banyaknya perdebatan mengenai soal-soal agama yang terjadi di antara kaum Muslimin di satu pihak dan orang-orang Yahudi-Nasrani di lain pihak. Untuk menghadapi perdebatan tersebut mereka memerlukan filsafat Yunani agar argumentasinya dapat disusun secara baik dalam mengimbangi lawannya yang terkenal memakai ilmu-ilmu Yunani, terutama logika.

2. Banyaknya kepercayaan dan pikiran yang masuk pada kaum Muslimin, seperti orang Iran misalnya, yang dalam menguatkan kepercayaan, mereka memakai ilmu berpikir yang berdasarkan filsafat Yunani. ${ }^{31}$

3. Kecenderungan al-Ma'mūn kepada aliran Mu'tazilah, sehingga mendorongnya untuk membela dan menguatkan pendiriannya, terutama dalam persoalan Kalāmullāh dengan argumentasi pemikiran. Persoalan tersebut menyangkut salah satu sifat Tuhan, yaitu sifat Kalām.

4. Kecenderungan al-Ma'mūn terhadap kebebasan berpikir serta pandangan yang positifnya terhadap para filosof sebagai manusia pilihan, dimana orang banyak harus mengambil pikiran-pikirannya.

5. Kondisi masa itu menghendaki adanya penerjemahan buku-buku bidang kedokteran, metafisika, astronomi dan lain sebagainya, dengan dorongan yang kuat dari penguasa. ${ }^{32}$

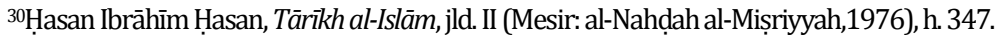

${ }^{31}$ A. Hanafi, Pengantar Filsafat Islam, h. 49.

${ }^{32}$ Abu Ahmadi, Filsafat Islam, h. 61-62. 
Kegiatan penerjemahan ini tetap berjalan sepeninggal al-Ma'mūn dalam waktu yang cukup lama, meskipun Khalifah al-Mutawakkil (847-861 M) membatasi kebebasan berpikir dan menindak orang-orang yang bekerja di lapangan filsafat. Akan tetapi, secara pribadi atau kelompok masyarakat yang cinta kepada ilmu tetap meneruskan kegiatan penerjemahan bahkan di lengkapi dengan berbagai catatan dan komentar. Selanjutnya umat Islam dalam waktu yang relatif singkat dapat menguasai warisan intelektual dari tiga jenis kebudayaan yang sangat maju pada waktu itu yakni, Yunani, Persia dan India.

Berkat kegiatan penerjemahan tersebut, lahirlah para filosof Islam sebagai penerus pemikiran umat manusia, bahkan telah melampauinya dalam sebagian aspek, meski harus mengambil hal-hal yang perlu dari filsafat Yunani, Romawi dan lainnya. Mereka juga memberikan andil dalam rangka memperbaiki dan menambah hal-hal baru kepadanya, di samping membentangkan jalan bagi filsafat yang datang sesudahnya. Mereka membangkitkkan pikiran Yahudi dari tidurnya, mendorong secara kuat pikiran Masehi, dan membantu serta memberi daya kekuatan kepada tokoh-tokoh renaissance dan filosof abad modern. ${ }^{33}$

Adalah wajar, jika didapati umat Islam pada abad pertengahan terdorong untuk menyelami alam pikiran bangsa lain dalam rangka memperluas cakrawala pemikiran. Paling tidak ada tiga faktor internal umat Islam melakukan hal ini, yaitu:

1. Lebarnya jurang perbedaan antara Islam yang berdasarkan wahyu, meskipun tanpa mengecilkan peranan akal, dengan filsafat Aristoteles yang berdasarkan akal semata-mata.

2. Kecaman yang di lakukan oleh pemuka agama terhadap pembahasan rasional, yang kesimpulannya tidak terikat dengan ketentuan akidah yang telah diakui sebelumnya.

3. Kegemaran para filosof Muslim itu sendiri untuk hidup tenang agar dapat berpikirdan bebas dari berbagai petaka dan kekacauan. ${ }^{34}$

Dengan adanya tiga faktor di atas, di samping faktor-faktor yang lain, maka kegiatan penerjemahan buku-buku filsafat ke dalam bahasa Arab berlangsung

33Ibrahim Madzkur, Fi al-Falsafat al-Islāmiyyah Manhaj wa Tațbīquh, terj. Yudian A. Asmi A.N. Mudzakkir (Jakarta: Rajawali.. 1988), h. 288.

${ }^{34}$ Ahmad Daudy, Kuliah Filsafat Islam, h. 8-9. 
dalam waktu yang relatif singkat dengan hasil penerjemahan yang cukup banyak. Buku-buku filsafat yang berhasil diterjemahkan antara lain karya Plato (427-347 SM) yang meliputi: buku tentang argumentasi dan ke-Tuhanan dalam bentuk percakapan, dengan judul theatetus, cratylus, sophistes dan parmenides. Buku tentang fisika berjudul timaeus, buku tentang psikologi dan akhlak berjudul phaedo dan phaedrus, dan buku tentang politik berjudul politicus dan laws yang diterjemahkan oleh Yahyā bin 'Adīj.35

Sedangkan karya Aristoteles adalah yang paling banyak di terjemahkan meliputi: buku tentang semantic (logika) terdiri dari buku Cathegories (alMuqawwalāt), Parearmenias (al-Ibrah), Analytica Priora (al-Qiyās), Analitica Posteriora (al-Burhān), Topica (al-Jadal), dan Sofistica (al-Aqwāl al Mughallizah). ${ }^{36}$ Keenam buku itu dikenal di kalangan Yunani dengan nama Organon yang berarti alat, yakni alat untuk berpikir yang menjamin menghasilkan kebenaran. Sedang buku tentang fisika ada tiga buah berjudul; de Caelo (langit), Animalium (hewan) dan Anima (jiwa). Buku tentang etika ada satu berjudul Etica Necomachaea dan satu buku tentang metafisika berjudul Metaphysica.

Sementara itu ada buku-buku masa hellennisme Romawi yang sampai kepada umat Islam yaitu, buku Introduction to Arithmettic karya Nicomachus dan buku Poimandres (the Good Shephered) yang berisi percakapan antara akal ke-Tuhanan (logos) dengan muridnya Hermes. Selanjutnya buku-buku masa Neo-Platonisme yang di terjemahkan ke dalam bahasa Arab cukup banyak, di antaranya ialah buku Enneads (kesembilanan) karya Plotinus dari Mesir, pendiri aliran Neo-Patonisme, buku Teologia (ketuhanan) yang merupakan buku pilihan dari Enneads, buku Isagoge karya porphyries yang berarti pengantar, buku tentang qadim-nya alam dan Element of Theology (dasar-dasar ilmu KeTuhanan) karya Proculs. ${ }^{37}$ Melalui buku-buku di atas, umat Islam mengenal filsafat Yunani dengan berbagai alirannya, kemudian dikaji sedemikian rupa, sehingga mereka akhirnya dapat neyusun karya-karya filsafat Islam yang memiliki ciri khas dan kepribadian sendiri, yakni sinkretis (perpaduan) dan eklektis (ikhtiyār).

35Poerwantana, dkk, Seluk Beluk Filsafat, h. 89-90.

${ }^{36}$ Ahmmad Fuād al-Akhwāni, al-Falsafah al-Islāmiyyah, h. 43-44 .

37Poerwantana, dkk., Seluk Beluk Filsafat, h. 91-95. 


\section{E. Kesimpulan}

Berangkat dari uraian di atas, penulis dapat mengambil beberapa kesimpulan sebagai berikut:

Pertama, kaum Muslimin pada abad pertama dan awal abad kedua Hijriyah (masa Bani Umayyah) telah mengenal filsafat Yunani, dan telah memulai menyalin buku-buku Yunani ke dalam bahasa Arab.

Kedua, filsafat Yunani yang sampai pada dunia Islam tidaklah semuanya orisinil seperti yang ditinggalkan orang-orang Yunani sendiri, tetapi telah melalui pemikiran hellenisme Romawi yang memiliki ciri dan corak tertentu. Jika pemikiran filsafat Yunani cenderung bersifat teoritis, maka filsafat hellenisme Romawi lebih bercorak praktis.

Ketiga, faktor utama bagi kaum Muslimin yang beraliran rationalis mempelajari filsafat Yunani-Romawi adalah dengan dalih untuk membela keyakinan agama terhadap kritik yang berasal dari umat non-Muslim. Dengan kata lain, kecondongan umat Islam pada waktu itu untuk dapat menyampaikan ajaran agama Islam secara rasional kepada umat non-Muslim, agar dapat di terima oleh mereka secara sadar dan tanpa adanya keraguan.]

\section{DAFTAR PUSTAKA}

Salam, Abdus, Sains dan Dunia Islam, terj. Pustaka, Bandung: Pustaka, 1983.

Ahmadi, Abu, Filsafat Islam, Semarang: Thoha Putra, 1982.

Aḥmad Fuād al-Akhwāni, al-Falsafah al-Islāmiyyah, terjemahan, Jakarta: Pustaka Firdaus, 1985.

Amīn, Aḥmad, Fajr al-Islām, Mesir: al-Nahḍah al-Miṣriyyah, 1965.

Basori, A. Chairil, Filsafat, Semarang: IAIN Walisongo, 1987.

Daudy, Ahmad, Kuliah Filsafat Islam, Jakarta: Bulan Bintang, 1986.

Seni-seni Pemikiran Filsafat dalam Islam, Jakarta: Bulan Bintang, 1986.

De Boer, The History of Philosophy in Islam,translated by Edward R. Jones, New York: Dover Publication INC, 1967. 
Hanafi, A., Pengantar Filsafat Islam. Jakarta: Bulan Bintang, 1978. Teologi Islam, Jakarta: Bulan Bintang, 1974.

3̣̣asan Ibrāhīm Ḥasan, Tārīkh al-Islām, jld.II, Mesir: al-Nahḍah, 1976.

al-Nashār, Ali Shāmī, Manāhij al-Baḥthi 'Inda Mufakkir al-Islām, Dārul Fikr al'Arabī, 1994.

Madzkur, Ibrahim, Fi al-Falsafat al-Islämiyyah Manhaj wa Tațbīquh, terj. Yudian A. Asmi A.N. Mudzakkir, Jakarta: Rajawali, 1988.

Nasution, Harun, Filsafat dan Mistisime dalam Islam, Jakarta: Bulan Bintang, 1979. Teologi Islam, Jakarta,Yayasan Penerbit UI, 1972.

Poedjawijatna, Pembimbing ke Arah Filsafat, Jakarta: PT. Pembangunan, 1980

Poerwantana, dkk,, Seluk Beluk Filsafat Islam, Bandung: Rosda, 1988.

al-Shahrastanī, al-Milal wa al-Niḥal, Juz I, Mesir: al-Qāhirah, 1320 H.

Syalabi, A., Mausū’at al-Tārīkh al-Islām, jilid II, Mesir: al-Nahḍah, 1971.

Sejarah Kebudayaan Islam, Jakarta: Pustaka al-Husna, 1987.

Watt, Montgomery, Islamic Theology and Philosophy, terj. Umar Basalim, Jakarta: P3M, 1987. 
